\title{
Effect on feed intake, milk production and milk composition of Holstein cows by replacing maize grain with wheat in total mixed rations
}

\author{
C.J.C. Muller ${ }^{1, \#, ~ J . A . ~ B o t h a ~}{ }^{1}$, F. Calitz ${ }^{2} \&$ M. Lehmann ${ }^{3}$ \\ ${ }^{1}$ Western Cape Department of Agriculture, Research and Technology Development Services, Directorate: Animal \\ Sciences, Private Bag X1, Elsenburg 7607, South Africa \\ ${ }^{2}$ ARC-Biometry Unit, Private Bag X5038, Stellenbosch 7602, South Africa \\ ${ }^{3}$ School of Natural Resource Management, Agriculture Management Programme, Nelson Mandela Metropolitan \\ University, George 6530, South Africa
}

(Received 3 May 2013; Accepted 19 May 2014; First published online 22 September 2014)

\author{
Copyright resides with the authors in terms of the Creative Commons Attribution 2.5 South African Licence. \\ See: http://creativecommons.org/licenses/by/2.5/za \\ Condition of use: The user may copy, distribute, transmit and adapt the work, but must recognise the authors and the South African \\ Journal of Animal Science.
}

\begin{abstract}
The effect of replacing maize grain with wheat as an energy source in total mixed rations (TMRs) on feed intake and milk yield parameters was determined for dairy cows. Three feeding trials were conducted using different roughages, namely lucerne hay $(\mathrm{LH})$, oat hay $(\mathrm{OH})$ and a $50: 50$ mixture of $\mathrm{LH}$ and $\mathrm{OH}$. For each trial, five TMRs were formulated in which the maize to wheat grain ratios were $100: 0,75: 25,50: 50$, $25: 75$ and $0: 100$ to contain at least $170 \mathrm{~g}$ crude protein (CP)/kg and $11.1 \mathrm{MJ} \mathrm{ME} / \mathrm{kg}$ dry matter. In each experiment, 10 randomly selected Holstein cows were fed the five diets according to a double $5 \times 5$ Latin square experimental design. In the trial using $\mathrm{LH}$ as roughage source, the fat percentage of milk, and therefore fat yield, was lower in the treatment containing only wheat as an energy source. In the trial using a 50 : 50 mixture of $\mathrm{LH}$ and $\mathrm{OH}$ as roughage source, the fat content of milk increased with rising levels of wheat in the diet. No differences were observed in any of the other milk yield parameters by increasing the wheat inclusion levels in diets. The feed intake of cows receiving TMRs containing only LH as roughage source was reduced with increasing levels of wheat in diets. Results showed no conclusive negative results associated with the replacement of maize grain with wheat grain.
\end{abstract}

Keywords: Alfalfa hay, energy sources, inclusion level, milk yield parameters, oat hay, wheat

\#Corresponding author: carelm@elsenburg.com

\section{Introduction}

The majority of dairy farmers in the Swartland region of the Western Cape feed total mixed rations (TMRs) to lactating dairy cows, because there is a dearth of cultivated pastures in the area. The region has a winter rainfall pattern with long dry summers, resulting in limited water for irrigation. The use of cultivated pastures year-round in feeding dairy cows is not a viable option. Total mixed rations are formulated and mixed to meet the nutritional needs of dairy cows, taking lactation number, milk yield level and stage of lactation into account. Roughages for dairy cows in this area include lucerne hay (LH), oat hay $(\mathrm{OH})$ and various cereal crops that are conserved as silage, wheat straw or wheat straw treated with ammonia. Combinations of these roughages are often fed. The energy in TMRs is provided by including grains such as maize (Zea mays), barley (Hordeum sativum), wheat (Triticum aestivum) and cereal crop by-products such as wheat middlings. Mainly maize is used as the energy source in the diets of dairy cows.

Wheat, a winter cereal, is the main grain crop in the Western Cape. Seasonal summer droughts in the maize-producing areas can cause maize shortages for dairy farmers there, forcing them to rely on imported maize. The cost of home-produced wheat grain could be lower than maize grain, largely owing to high transportation costs associated with importing maize grain to the Western Cape. This would make economic sense to use wheat grain in TMRs for dairy cows. However, it is not commonly used as a feed source for dairy cows possibly because of certain perceptions. It has been shown that the rate of the in vitro disappearance of starch in wheat is higher than that of maize (Stock et al., 1990). Large quantities of wheat in the diets of dairy cows change the bacterial population in the rumen, increasing lactic acid production, with the result that the rumen content becomes more acidic. The $\mathrm{pH}$ level is lowered because of an increase in the concentration of volatile fatty acids (VFAs) caused by the fermentation of the carbohydrate fraction of the diet. This process may cause acidosis. The symptoms of acute acidosis are rumen stasis, rumenitis, 
diarrhoea, dehydration, laminitis and liver abscesses (McSweeney \& Mackie, 1997). Experimental design seems to affect milk yield parameters when comparing wheat- and corn-based diets. A long-term study (Petit \& Santos, 1996) in which a lower level of wheat intake was used, resulted in a higher milk yield in comparison with a corn-based diet, while in a short-term study, Gulmez et al. (2010) recorded a lower milk yield for cows consuming wheat- versus corn-based diets. In this trial, the concentrate level was also higher.

The effect of feeding high levels of wheat grain in TMRs for dairy cows using local roughages has not been determined for South African farming conditions. Neither has the optimal inclusion level for wheat grain in dairy cow rations been established. The aim of this study was to determine the effect of wheat grain replacing maize grain in TMRs on the feed intake and milk yield parameters of lactating Holstein cows using different roughages, that is, $\mathrm{LH}, \mathrm{OH}$ and a $50: 50$ combination of $\mathrm{LH}$ and $\mathrm{OH}$. It was postulated that the feed intake of diets containing higher levels of wheat would be lower than diets containing similar amounts of maize, consequently having a negative effect on milk yield.

\section{Materials and Methods}

The study, which comprised three feeding trials using different roughage and energy sources, was conducted at Elsenburg Research Farm, Western Cape Department of Agriculture. Elsenburg is situated in the winter rainfall region of South Africa, approximately $12 \mathrm{~km}$ north of Stellenbosch at an altitude of 177 metres, longitude $18^{\circ} 50^{\prime}$ and latitude $33^{\circ} 51^{\prime}$.

Ten randomly selected Holstein cows were allocated to each of the three trials. Data on the cows used in the study at the start of the three trials are presented in Table 1. Cows were at least 60 days post calving at the start of each experiment.

Table 1 Data (means \pm SD) of cows at the start of three trials using different roughage sources

\begin{tabular}{lccc}
\hline Parameters & $\begin{array}{c}\text { Lucerne hay (LH) } \\
\text { Experiment 1 }\end{array}$ & $\begin{array}{c}\text { Oat hay (OH) } \\
\text { Experiment 2 }\end{array}$ & $\begin{array}{c}\mathbf{5 0}: \mathbf{5 0} \text { mixture LH : OH } \\
\text { Experiment 3 }\end{array}$ \\
\hline Average days post-partum & $62 \pm 2.4$ & $62 \pm 2.5$ & $59 \pm 1.8$ \\
Average milk yield (kg/day) & $24.9 \pm 2.4$ & $30.5 \pm 4.0$ & $28.6 \pm 4.7$ \\
Average number of lactations & $1.3 \pm 0.5$ & $2.4 \pm 1.0$ & $1.5 \pm 0.5$ \\
\hline
\end{tabular}

The experiments consisted of three different roughage sources, viz. $\mathrm{LH}, \mathrm{OH}$ and a $50: 50$ mixture of $\mathrm{LH}$ and $\mathrm{OH}$, with the relevant combinations of wheat and maize as the energy supplements. For each roughage source, five TMR diets were formulated in which the maize to wheat grain ratio was $100: 0$, $75: 25,50: 50,25: 75$ and $0: 100$. In each trial the five diets were fed to 10 cows in a double cross-over $5 \times 5$ Latin square experimental design (MacFie et al., 1989).

The ingredients of the experimental diets in the three experiments are presented in Table 2. Diets were formulated to contain at least $170 \mathrm{~g} \mathrm{CP} / \mathrm{kg}$ and $11.1 \mathrm{MJ} \mathrm{ME} / \mathrm{kg} \mathrm{DM}$. Wheat straw was used as filler material towards a standard mixing amount. Because wheat normally contains slightly higher levels of CP than maize, the CP content of the diets was balanced by including urea in the diets. Rations were mixed as required in a Himomix mixer/feeder wagon (Overberg Agri, Caledon). The roughage component of the ration was milled prior to mixing, to provide fragments with cut-lengths of 5 to $10 \mathrm{~cm}$. The maize and wheat grain were coarsely milled, using a Drotsky hammermill (Drotsky, Alrode, Alberton) before the appropriate quantities for each ration were weighed out, using an Avery Berkel model L120 scale. One ton of each diet was mixed at a time, and bagged down for ease of feeding.

In each of the three experiments, each cow received a specific diet for a five-week period. This comprised an initial 14-day adaptation period, followed by a 21-day trial period, during which the relevant data were recorded. Cows were kept in a closed barn in separate stalls measuring $4 \times 4 \mathrm{~m}$. Diets were fed twice a day after each milking at 07:00 and 16:00. Sufficient amounts of feed were placed in each cow's feed bin to ensure an ad libitum daily feed intake. A maximum of 5\% wastage per day was allowed. Clean drinking water was available at all times. Stalls were cleaned every day, and fresh straw was placed on the concrete floor to ensure a clean and comfortable sleeping area. Cows were let out between 10:30 and 13:30 into open paddocks for heat detection and grooming. The paddocks contained bare soil with no edible material. Cows were milked twice a day at 06:00 and 15:00 in a milking parlour approximately $100 \mathrm{~m}$ from the housing barn. Standard operating procedures were followed. Cows were brought into the parlour, the udders were washed with running water, after which the teats and most of the udder were dried with a disposable paper towel. 
The milk yield of each cow was recorded at each milking session. During the three-week trial period, proportionate milk samples were collected from each cow at the morning and afternoon milking on Mondays, Tuesdays and Wednesdays. The morning and afternoon milk samples were combined and analysed for fat, protein and lactose content, as well as milk urea nitrogen (MUN) at LactoLab (Pty), Irene laboratory.

Table 2 Ingredients (on "as is" basis) of experimental diets containing different roughage sources: lucerne hay ( $\mathrm{LH}$, Experiment 1), oat hay $(\mathrm{OH}$, Experiment 2) and a $50: 50$ mixture of $\mathrm{LH}$ and $\mathrm{OH}$ (Experiment 3 ) and different ratios of maize and wheat grain as energy sources

\begin{tabular}{|c|c|c|c|c|c|c|}
\hline \multirow{2}{*}{ Experiment } & \multirow{2}{*}{ Ingredients } & \multicolumn{5}{|c|}{ Maize : wheat ratio in total mixed rations } \\
\hline & & $100: 0$ & $75: 25$ & $50: 50$ & $25: 75$ & $0: 100$ \\
\hline \multirow{10}{*}{1} & Lucerne hay (kg) & 420 & 420 & 420 & 420 & 420 \\
\hline & Maize $(\mathrm{kg})$ & 448 & 336 & 224 & 112 & 0 \\
\hline & Wheat (kg) & 0 & 120.5 & 241 & 361.5 & 482 \\
\hline & Wheat bran (kg) & 35 & 35 & 35 & 35 & 35 \\
\hline & Wheat straw (kg) & 24 & 18 & 12 & 6 & 0 \\
\hline & CSOCM (kg) & 54 & 54 & 54 & 54 & 54 \\
\hline & Urea (kg) & 8 & 6.25 & 4.5 & 2.75 & 1 \\
\hline & MoCaP (kg) & 4.0 & 3.25 & 2.5 & 1.75 & 1.0 \\
\hline & Salt (kg) & 5 & 5 & 5 & 5 & 5 \\
\hline & Limestone (kg) & 2 & 2 & 2 & 2 & 2 \\
\hline \multirow{10}{*}{2} & Oat hay (kg) & 446 & 439 & 432 & 425 & 418 \\
\hline & Maize $(\mathrm{kg})$ & 310 & 232.5 & 155 & 77.5 & 0 \\
\hline & Wheat (kg) & 0 & 83.5 & 167 & 250.5 & 334 \\
\hline & Wheat bran (kg) & 30 & 30 & 30 & 30 & 30 \\
\hline & CSOCM $(\mathrm{kg})$ & 134 & 137 & 140 & 143 & 146 \\
\hline & SBOCM (kg) & 50 & 50 & 50 & 50 & 50 \\
\hline & Urea (kg) & 10 & 8.5 & 7 & 5.5 & 4 \\
\hline & $\mathrm{MoCaP}(\mathrm{kg})$ & 2.5 & 2.0 & 1.5 & 1.0 & 0.5 \\
\hline & Salt $(k g)$ & 5 & 5 & 5 & 5 & 5 \\
\hline & Limestone (kg) & 12.5 & 12.5 & 12.5 & 12.5 & 12.5 \\
\hline \multirow{10}{*}{3} & Lucerne hay (kg) & 220 & 220 & 220 & 220 & 220 \\
\hline & Oat hay (kg) & 220 & 220 & 220 & 220 & 220 \\
\hline & Maize $(\mathrm{kg})$ & 300 & 225 & 150 & 75 & 0 \\
\hline & Wheat (kg) & 0 & 92 & 184 & 276 & 368 \\
\hline & Wheat bran (kg) & 40 & 40 & 40 & 40 & 40 \\
\hline & Wheat straw (kg) & 30 & 23.5 & 17 & 10.5 & 4 \\
\hline & CSOCM (kg) & 177 & 166.5 & 156 & 145.5 & 135 \\
\hline & Urea (kg) & 1 & 1 & 1 & 1 & 1 \\
\hline & Salt $(k g)$ & 5 & 5 & 5 & 5 & 5 \\
\hline & Limestone (kg) & 7 & 7 & 7 & 7 & 7 \\
\hline
\end{tabular}

A 1000-kg capacity BERKEL electronic scale was used to weigh the cows. Weighing took place after the afternoon milking at the beginning and end of each experimental period. The body condition score (BCS) and locomotion score (LS) of each cow were recorded at the same time. The Mulvany (1977) system was 
used for condition scoring of cows, and Berry \& Cook's (2000) locomotion activity scoring system for cows, was utilized.

During the three-week trial period, the daily dry matter intake (DMI) of each individual cow was determined three times a week. A sufficient amount of the mixed ration to ensure an ad libitum intake was provided daily. Half the daily feed requirement was put into the feed troughs after the evening milking and the other half after milking the following morning. Feed intake was calculated as the weight of the total amount of feed weighed into the feed trough for each cow minus the weight of the orts. A sample of approximately $500 \mathrm{~g}$ was collected from the orts of each trough for DM determination. The sample was placed in a drying pan, weighed and placed in a draught oven (Labotec Model 364) at $100{ }^{\circ} \mathrm{C}$ for $24 \mathrm{~h}$. The following day, the dried sample was weighed again and the DM content of the residue was calculated as the proportion by weight of the sample remaining after drying. To ensure ad libitum daily feed intake, the TMR amount fed was adjusted after determining each DMI.

A sample of each of the experimental diets was collected each time that the feed intake was determined. Samples were dried at $55^{\circ} \mathrm{C}$ in a forced-air oven for $72 \mathrm{~h}$, milled through a $1 \mathrm{~mm}$ sieve (Christy \& Norris Laboratory Mill, B\&M Scientific, Millenium Park, Parow Industria, Parow), then submitted for chemical analysis. The CP, crude fibre (CF), acid detergent fibre (ADF) and neutral detergent fibre (NDF) contents of the samples were determined according to the methods of the AOAC (1995). The following equation (Ensminger et al., 1990) was used to calculate the total digestible nutrient (TDN) content of feeds: TDN \% $=\left(0.8^{\star} \mathrm{CP} \%\right)+\left(0.4^{\star} \mathrm{CF} \%\right)+\left(0.9^{\star} \mathrm{NFE} \%\right)+\left(0.9^{\star} 2.25^{\star} \mathrm{EE} \%\right)$.

The metabolizable energy content of feeds was derived from TDN values using the following equation: $\mathrm{TDN}^{*} 0.15=\mathrm{ME} \mathrm{MJ} / \mathrm{kg}$ DM (Bredon et al., 1987).

Table 3 Mean chemical composition of total mixed rations (TMRs) containing different maize and wheat ratios, i.e. $100: 0,75: 25,50: 50,25: 75,0: 100$, together with lucerne hay (LH), oat hay (OH), and $0: 50$ $\mathrm{LH}: \mathrm{OH}$ as roughage sources (values are depicted on a DM basis)

\begin{tabular}{|c|c|c|c|c|c|c|}
\hline \multirow{2}{*}{$\begin{array}{l}\text { Experiment } \\
\text { (roughage) }\end{array}$} & \multirow{2}{*}{ Ingredients } & \multicolumn{5}{|c|}{ Maize : wheat ratio in TMRs } \\
\hline & & $100: 0$ & $75: 25$ & $50: 50$ & $25: 75$ & $0: 100$ \\
\hline \multirow{7}{*}{$1(\mathrm{LH})$} & Crude protein $(\mathrm{g} / \mathrm{kg})$ & 160 & 172 & 172 & 175 & 179 \\
\hline & Crude fibre $(\mathrm{g} / \mathrm{kg})$ & 194 & 189 & 177 & 181 & 199 \\
\hline & ME (MJ/kg DM) & 11.4 & 11.3 & 11.4 & 11.3 & 11.0 \\
\hline & Acid detergent fibre $(\mathrm{g} / \mathrm{kg})$ & 227 & 231 & 211 & 216 & 229 \\
\hline & Neutral detergent fibre $(\mathrm{g} / \mathrm{kg})$ & 318 & 317 & 304 & 315 & 329 \\
\hline & Calcium (g/kg) & 6.6 & 6.9 & 6.4 & 7.2 & 6.9 \\
\hline & Phosphorus (g/kg) & 4.6 & 4.7 & 4.7 & 5.1 & 4.4 \\
\hline \multirow{6}{*}{$2(\mathrm{OH})$} & Crude protein $(\mathrm{g} / \mathrm{kg})$ & 198 & 206 & 201 & 216 & 210 \\
\hline & Crude fibre $(\mathrm{g} / \mathrm{kg})$ & 174 & 169 & 176 & 159 & 149 \\
\hline & $\mathrm{ME}(\mathrm{MJ} / \mathrm{kg} \mathrm{DM})$ & 11.3 & 11.3 & 11.3 & 11.4 & 11.1 \\
\hline & Acid detergent fibre $(\mathrm{g} / \mathrm{kg})$ & 210 & 179 & 237 & 197 & 200 \\
\hline & Neutral detergent fibre(g/kg) & 354 & 350 & 368 & 344 & 333 \\
\hline & Calcium (g/kg) & 8.2 & 8.4 & 8.0 & 7.0 & 9.9 \\
\hline \multirow{8}{*}{$\begin{array}{l}3 \text { (50\% LH: } \\
50 \% \text { OH) }\end{array}$} & Phosphorus (g/kg) & 5.5 & 4.9 & 5.6 & 5.4 & 9.7 \\
\hline & Crude protein $(\mathrm{g} / \mathrm{kg})$ & 178 & 178 & 173 & 169 & 168 \\
\hline & Crude fibre $(\mathrm{g} / \mathrm{kg})$ & 209 & 202 & 168 & 230 & 221 \\
\hline & ME (MJ/kg DM) & 11.3 & 11.3 & 11.2 & 11.1 & 11.1 \\
\hline & Acid detergent fibre $(\mathrm{g} / \mathrm{kg})$ & 266 & 257 & 260 & 281 & 277 \\
\hline & Neutral detergent fibre $(\mathrm{g} / \mathrm{kg})$ & 380 & 377 & 387 & 414 & 405 \\
\hline & Calcium (g/kg) & 6.6 & 6.2 & 6.1 & 6.1 & 6.3 \\
\hline & Phosphorus (g/kg) & 4.2 & 4.2 & 4.2 & 4.1 & 4.1 \\
\hline
\end{tabular}


Production data were analysed as a double cross-over $5 \times 5$ Latin square (Williams, 1948). Standardized residuals were calculated and used to test for deviations from normality using Shapiro-Wilk's test (Shapiro \& Wilk, 1965). Outliers were identified and removed before final analysis was performed. Means were adjusted for carry-over effects. The Student's t-LSD (least significant difference) was calculated at a $5 \%$ significance level to compare means for significant effects. Best-fit regression coefficients were used after the convergence of the sum of squares. All analysis was done using SAS ver. 9.1 statistical software (SAS, 1999).

\section{Results and Discussion}

The chemical composition of all the TMRs collected once a week during the three experiments is presented in Table 3. The CP content of the diets in Experiments 1 and 2 showed higher absolute values with higher wheat levels, probably indicating that wheat grain in the diets had a higher CP content than values obtained from the literature. Such a trend was not observed with the other parameters that were analysed.

The effect of wheat inclusion level on the DMI, BCS, body weight and LS of Holstein cows receiving TMRs containing LH (Experiment 1), $\mathrm{OH}$ (Experiment 2) and a $50: 50$ mixture of $\mathrm{LH}$ and $\mathrm{OH}$ (Experiment 3) is presented in Table 4. In Experiment 1 the feed intake of cows decreased $(P<0.05)$ when receiving diets containing increasing levels of wheat. Although the feed intake of cows in Experiments 2 and 3 was $7 \%$ and $5 \%$ lower, respectively, at $100 \%$ wheat inclusion level in comparison to $100 \%$ maize inclusion level, reductions in feed intake were not significant $(P>0.05)$. The increasing inclusion levels of wheat in the experimental diets of Experiment 1 had no effect $(P>0.05)$ on the LS of cows. This is not conclusive as the short trial period probably prevented the deterioration of the locomotion score of cows, which is typically associated with acidotic conditions. For this reason the LS of cows was not determined for Experiments 2 and 3.

Table 4 Least square means \pm SE of wheat inclusion level on dry matter intake (DMI), body weight (BW), body condition score (BCS) and locomotion score (LS) of Holstein cows receiving total mixed rations (TMRs) containing lucerne hay (Experiment 1), oat hay (Experiment 2) and a $50: 50$ mixture of lucerne hay and oat hay (Experiment 3)

\begin{tabular}{|c|c|c|c|c|c|c|}
\hline \multirow[b]{2}{*}{ Parameters } & \multicolumn{5}{|c|}{ Maize : wheat in TMRs } & \multirow{2}{*}{$P$-values } \\
\hline & $100: 0$ & $75: 25$ & $50: 50$ & $25: 75$ & $0: 100$ & \\
\hline \multicolumn{7}{|l|}{ Experiment 1} \\
\hline DMI (kg/cow/day) & $20.2^{\mathrm{bcd}} \pm 0.4$ & $19.6^{\mathrm{a}} \pm 0.4$ & $18.8^{d} \pm 0.4$ & $18.7^{c} \pm 0.4$ & $17.9^{\mathrm{ab}} \pm 0.4$ & 0.002 \\
\hline BW at start (kg) & $505 \pm 5$ & $512 \pm 5$ & $508 \pm 5$ & $516 \pm 5$ & $517 \pm 4$ & 0.30 \\
\hline BW at end $(\mathrm{kg})$ & $511 \pm 6$ & $516 \pm 6$ & $515 \pm 6$ & $520 \pm 6$ & $519 \pm 5$ & 0.82 \\
\hline BCS at start & $1.9 \pm 0.1$ & $2.1 \pm 0.1$ & $1.9 \pm 0.1$ & $2.1 \pm 0.1$ & $2.1 \pm 0.1$ & 0.10 \\
\hline BCS at end & $2.0 \pm 0.1$ & $2.0 \pm 0.1$ & $2.0 \pm 0.1$ & $2.1 \pm 0.1$ & $1.9 \pm 0.1$ & 0.17 \\
\hline LS at start & $1.5 \pm 0.1$ & $1.3 \pm 0.1$ & $1.4 \pm 0.1$ & $1.3 \pm 0.1$ & $1.3 \pm 0.1$ & 0.90 \\
\hline LS at end & $1.3 \pm 0.1$ & $1.3 \pm 0.1$ & $1.3 \pm 0.1$ & $1.2 \pm 0.1$ & $1.3 \pm 0.1$ & 0.95 \\
\hline \multicolumn{7}{|l|}{ Experiment 2} \\
\hline DMI (kg/cow/day) & $22.6 \pm 0.7$ & $21.9 \pm 0.7$ & $21.9 \pm 0.7$ & $22.3 \pm 0.7$ & $21.1 \pm 0.6$ & 0.52 \\
\hline BW at start $(\mathrm{kg})$ & $594 \pm 5$ & $589 \pm 5$ & $593 \pm 5$ & $591 \pm 5$ & $592 \pm 5$ & 0.97 \\
\hline BW at end $(\mathrm{kg})$ & $602^{a} \pm 4$ & $595^{a} \pm 4$ & $602^{a} \pm 4$ & $603^{a} \pm 4$ & $585^{b} \pm 4$ & 0.01 \\
\hline BCS at start & $2.3 \pm 0.1$ & $2.2 \pm 0.1$ & $2.2 \pm 0.2$ & $2.1 \pm 0.1$ & $2.3 \pm 0.1$ & 0.82 \\
\hline BCS at end & $2.1 \pm 0.1$ & $2.4 \pm 0.2$ & $2.4 \pm 0.2$ & $2.4 \pm 0.2$ & $2.4 \pm 0.2$ & 0.58 \\
\hline \multicolumn{7}{|l|}{ Experiment 3} \\
\hline DMI (kg/cow/day) & $20.7 \pm 0.6$ & $20.4 \pm 0.6$ & $21.1 \pm 0.5$ & $20.9 \pm .0 .5$ & $19.8 \pm 0.6$ & 0.53 \\
\hline BW at start $(\mathrm{kg})$ & $570 \pm 14$ & $562 \pm 17$ & $556 \pm 12$ & $548 \pm 20$ & $538 \pm 18$ & 0.79 \\
\hline BW at end $(\mathrm{kg})$ & $538 \pm 15$ & $562 \pm 24$ & $541 \pm 21$ & $590 \pm 21$ & $569 \pm 33$ & 0.56 \\
\hline BCS at start & $2.1 \pm 0.1$ & $2.1 \pm 0.1$ & $2.1 \pm 0.1$ & $2.2 \pm 0.1$ & $2.1 \pm 0.1$ & 0.85 \\
\hline BCS at end & $2.2 \pm 0.1$ & $2.3 \pm 0.1$ & $2.3 \pm 0.1$ & $2.4 \pm 0.1$ & $2.3 \pm 0.1$ & 0.80 \\
\hline
\end{tabular}

$\overline{a, b, c, d}$ Means with the same superscript letter do not differ significantly at a 5\% significant level. 
The effect of the inclusion level of wheat in TMRs for dairy cows on milk yield parameters is presented in Table 5. With the exception of fat percentage in Experiments 1 and 3, milk yield parameters were not affected $(P>0.05)$ by energy source. Although the milk yield of cows in Experiment 1 was reduced by 6\% and $7 \%$ at $25 \%$ and $50 \%$ wheat inclusion levels, respectively, though this effect was not significant $(P>0.05)$. The same trend was observed in Experiment 2 with a $7 \%$ reduction in milk yield between the TMRs containing $100 \%$ maize and $100 \%$ wheat, respectively. The ANOVA and regression analysis (Table 7) both indicated that there were not enough evidence for significance at $P<0.05$. Milk urea nitrogen content was not affected $(P>0.05)$ by the inclusion level of wheat in the diets of all three experiments.

Table 5 Effect of the inclusion level of wheat on daily milk, fat and protein yield and milk composition of Holstein cows receiving total mixed rations (TMRs) containing lucerne hay (Experiment 1), oat hay (Experiment 2) and a 50:50 mixture of lucerne hay and oat hay (Experiment 3)

\begin{tabular}{|c|c|c|c|c|c|c|}
\hline \multirow{2}{*}{ Parameters } & \multicolumn{5}{|c|}{ Maize : wheat ratio in TMRs } & \multirow{2}{*}{$P$-values } \\
\hline & $100: 0$ & $75: 25$ & $50: 50$ & $25: 75$ & $0: 100$ & \\
\hline $\begin{array}{l}\text { Experiment 1: } \\
\text { Milk }(\mathrm{kg})\end{array}$ & $23.6 \pm 0.8$ & $22.2 \pm 0.8$ & $21.9 \pm 0.8$ & $21.9 \pm 0.8$ & $22.5 \pm 0.7$ & 0.58 \\
\hline Fat $(\%)$ & $3.60^{\mathrm{a}} \pm 0.12$ & $3.59^{a} \pm 0.12$ & $3.63^{a} \pm 0.12$ & $3.33^{a} \pm 0.12$ & $3.07^{b} \pm 0.11$ & 0.01 \\
\hline Protein (\%) & $3.30 \pm 0.06$ & $3.32 \pm 0.06$ & $3.43 \pm 0.06$ & $3.48 \pm 0.06$ & $3.33 \pm 0.06$ & 0.20 \\
\hline Lactose (\%) & $4.85 \pm 0.03$ & $4.85 \pm 0.03$ & $4.84 \pm 0.03$ & $4.78 \pm 0.03$ & $4.88 \pm 0.03$ & 0.16 \\
\hline Fat (g) & $843^{a} \pm 0.02$ & $788^{a} \pm 0.02$ & $782^{a} \pm 0.02$ & $712^{\mathrm{a}} \pm 0.02$ & $674^{b} \pm 0.02$ & 0.01 \\
\hline Protein (g) & $780 \pm 0.6$ & $724 \pm 0.6$ & $739 \pm 0.6$ & $760 \pm 0.6$ & $768 \pm 0.5$ & 0.56 \\
\hline MUN & $20.9 \pm 0.6$ & $21.2 \pm 0.6$ & $20.5 \pm 0.6$ & $21.7 \pm 0.6$ & $21.2 \pm 0.5$ & 0.65 \\
\hline $\begin{array}{l}\text { Experiment 2: } \\
\text { Milk }(\mathrm{kg})\end{array}$ & $28.6 \pm 0.7$ & $26.9 \pm 0.7$ & $28.0 \pm 0.7$ & $28.1 \pm 0.7$ & $26.7 \pm 0.6$ & 0.19 \\
\hline Fat $(\%)$ & $3.43 \pm 0.03$ & $3.42 \pm 0.03$ & $3.31 \pm 0.03$ & $3.38 \pm 0.03$ & $3.40 \pm 0.03$ & 0.12 \\
\hline Protein (\%) & $3.09 \pm 0.03$ & $3.09 \pm 0.03$ & $3.02 \pm 0.03$ & $3.09 \pm 0.03$ & $3.11 \pm 0.03$ & 0.32 \\
\hline Lactose (\%) & $4.92 \pm 0.02$ & $4.87 \pm 0.02$ & $4.89 \pm 0.02$ & $4.89 \pm 0.02$ & $4.84 \pm 0.02$ & 0.12 \\
\hline Fat (g) & $980 \pm 0.04$ & $894 \pm 0.04$ & $924 \pm 0.04$ & $864 \pm 0.04$ & $931 \pm 0.04$ & 0.29 \\
\hline Protein (g) & $883 \pm 0.03$ & $805 \pm 0.04$ & $809 \pm 0.04$ & $801 \pm 0.04$ & $861 \pm 0.04$ & 0.40 \\
\hline MUN & $25.6 \pm 0.7$ & $27.0 \pm 0.7$ & $25.8 \pm 0.7$ & $26.2 \pm 0.7$ & $26.6 \pm 0.6$ & 0.55 \\
\hline $\begin{array}{l}\text { Experiment 3: } \\
\text { Milk }(\mathrm{kg})\end{array}$ & $23.1 \pm 0.8$ & $25.6 \pm 0.7$ & $24.4 \pm 0.7$ & $24.6 \pm 0.8$ & $24.6 \pm 0.8$ & 0.58 \\
\hline Fat $(\%)$ & $3.70^{\mathrm{a}} \pm 0.07$ & $3.79^{a} \pm 0.07$ & $3.92^{b} \pm 0.07$ & $3.63^{b} \pm 0.06$ & $4.02^{b} \pm 0.08$ & 0.01 \\
\hline Protein (\%) & $2.99 \pm 0.04$ & $3.08 \pm 0.04$ & $3.13 \pm 0.04$ & $3.10 \pm 0.04$ & $3.08 \pm 0.04$ & 0.12 \\
\hline Lactose (\%) & $4.72 \pm 0.03$ & $4.74 \pm 0.03$ & $4.75 \pm 0.03$ & $4.76 \pm 0.03$ & $4.77 \pm 0.03$ & 0.90 \\
\hline Fat (g) & $935 \pm 0.03$ & $927 \pm 0.03$ & $967 \pm 0.03$ & $933 \pm 0.03$ & $877 \pm 0.04$ & 0.36 \\
\hline Protein (g) & $744 \pm 0.04$ & $749 \pm 0.04$ & $780 \pm 0.03$ & $778 \pm 0.03$ & $723 \pm 0.04$ & 0.70 \\
\hline MUN & $19.5 \pm 0.8$ & $20.2 \pm 0.8$ & $19.2 \pm 0.7$ & $20.7 \pm 0.7$ & $20.5 \pm 0.9$ & 0.53 \\
\hline
\end{tabular}

${ }^{a, b}$ Means with the same superscript do not differ significantly at 5\%; MUN: milk urea nitrogen.

Varying results were obtained regarding the fat percentage in milk and milk fat yields. In Experiment 1 , fat yield differed $(P=0.01)$ among treatments with the highest fat yield recorded on the $100 \%$ maize inclusion level because of a lower $(P=0.01)$ fat percentage in the milk of cows receiving a diet containing $100 \%$ wheat as an energy source. However, in Experiment 2, the fat percentages did not differ $(P>0.05)$ among diets containing different wheat inclusion levels. Furthermore, in Experiment 3 , fat percentages differed $(P=0.01)$, with the highest milk fat percentage being obtained on the $100 \%$ wheat inclusion level, which is in contrast with the results in Experiment 1. The linear trends presented in Table 6 confirmed these results with only fat percentage in Experiment 1 showing a tendency $(P=0.06)$ to decline with increasing wheat inclusion levels. 
Table 6 Effect of increasing wheat levels on milk yield parameters of Holstein cows receiving total mixed rations as indicated by simple linear regression equations

\begin{tabular}{llcccc}
\hline $\begin{array}{l}\text { Experiment } \\
\text { (roughage) }\end{array}$ & Parameters & Intercept (a) & Slope (b) & ${ }^{*} \mathrm{R}^{2}(\%)$ & $P$-values \\
\hline & Milk (kg) & $23.17 \pm 0.71$ & $-0.25 \pm 0.21$ & 31 & 0.33 \\
& Fat (\%) & $3.84 \pm 0.15$ & $-0.13 \pm 0.04$ & 75 & 0.06 \\
1. Lucerne hay & Protein (\%) & $3.31 \pm 0.09$ & $0.02 \pm 0.03$ & 20 & 0.46 \\
& MUN & $20.75 \pm 0.49$ & $0.11 \pm 0.15$ & 16 & 0.50 \\
\hline & Milk (kg) & $28.44 \pm 0.86$ & $-0.26 \pm 0.26$ & 25 & 0.39 \\
& Fat (\%) & $3.42 \pm 0.05$ & $-0.01 \pm 0.02$ & 11 & 0.59 \\
& Protein (\%) & $3.07 \pm 0.04$ & $0.004 \pm 0.01$ & 3 & 0.77 \\
& MUN & $25.86 \pm 0.69$ & $0.12 \pm 0.21$ & 11 & 0.59 \\
\hline & Milk (kg) & $23.86 \pm 1.01$ & $0.20 \pm 0.31$ & 13 & 0.56 \\
3. 50\% lucerne hay: 50\% oat hay & Fat (\%) & $3.67 \pm 0.17$ & $0.05 \pm 0.05$ & 23 & 0.42 \\
& Protein (\%) & $3.02 \pm 0.05$ & $0.02 \pm 0.02$ & 37 & 0.28 \\
& MUN & $19.22 \pm 0.64$ & $0.27 \pm 0.19$ & 39 & 0.26
\end{tabular}

${ }^{*} R^{2}=$ the coefficient of determination (\% variation declared by the regression function).

These results were unexpected as it had been anticipated that the feed intake of cows, and therefore milk yield, would be reduced on diets containing high wheat levels. Feed intake was reduced only in Experiment 1 although milk yield was not affected $(P>0.05)$ by increasing wheat levels. The reason for varying results among the experiments is not clear, although the short duration of feeding periods could have affected results. Under practical farming conditions, a $6 \%$ or $7 \%$ reduction in milk yield would have considerable economic consequences.

Varying results concerning the effect of wheat inclusion level were obtained in other studies. Petit \& Santos (1996) found that Ayrshire cows fed high-moisture wheat tended $(P=0.12)$ to yield $1.6 \mathrm{~kg}$ of milk per day more than cows fed high-moisture maize. While the $4 \%$ fat corrected milk (FCM) yield of cows was higher $(P<0.05)$ for the wheat-based diet, milk composition was similar for cows fed concentrates containing high moisture wheat versus maize. These authors attributed the higher $4 \%$ FCM of cows fed high-moisture wheat to the higher in vitro digestibility of wheat compared with maize. In contrast, Gulmez et al. (2010) found that Holstein cows fed wheat-based diets produced less milk and 4\% FCM than cows fed corn-based diets. The lower milk yield is attributed to negative effects of ground wheat on ruminal digestion, i.e. low rumen $\mathrm{pH}$ and reduced cellulolytic activity. The experimental design and feeding regimen in the two studies differed, i.e. one being a long-term study over 3 years (Petis \& Santos, 1996) while the other (Gulmez et al., 2010) was a short term change-over design study consisting of $14 \mathrm{~d}$ adaptation period and $7 \mathrm{~d}$ measurement period. In the study by Petit \& Santos (1996) diets were fed four times a day, which could have led to more gradual starch fermentation and possibly higher digestibility over time. In the study by Gulmez et al. (2010) cows were fed twice a day, probably resulting in slug feeding, as cows tend to consume a large amount of feed at one session. This could have resulted in increased rumen acidity. In the study by Petit \& Santos (1996) the concentrate contents for wheat- and corn-based diets were only $35 \%$ and $41 \%$, respectively, while in the study by Gulmez et al. (2010) the concentrate content of both wheat and corn-based diets was higher at 50\%. The higher concentrate level in the diets of cows in the study by Gulmez et al. (2010) could have resulted in the poorer performance for cows consuming a wheat-based diet. In the present study wheat intake was $48 \%, 33 \%$ and $37 \%$ of the daily feed intake for diets containing $\mathrm{LH}, \mathrm{OH}$ and a $50: 50$ mixture of $\mathrm{LH}$ and $\mathrm{OH}$ as roughage sources, respectively.

Because wheat is not commonly used in dairy cow diets, a number of studies reported in the literature are based on using barley or triticale to replace maize as an energy source (Doepel et al., 2006). Barley and triticale (hybrid cereal developed from crossing wheat with rye) should have similar digestive characteristics to wheat. Wheat and triticale are similar in protein content (McDonald et al., 1988c). Performance studies by Erickson (1985) showed that triticale could replace at least $50 \%$, if not $100 \%$, of all cereal grains if it is introduced gradually with an equal weight of maize (corn) or wheat for non-ruminants and ruminants. Smith et al. (1994) conducted a milk production trial with Holstein cows where maize in the concentrate portion of 
the diet was replaced with various levels of a triticale cultivar (USGEN 10). Milk fat percentage was lower ( $P$ $<0.05$ ) on the $100 \%$ triticale diet compared with the $66 \%, 34 \%$ and $0 \%$ triticale diets, namely $2.65 \%, 3.52 \%$, $3.56 \%$ and $3.57 \%$, respectively. Replacing $66 \%$ of the maize in concentrates with a triticale cultivar did not result $(P>0.05)$ in a lower milk yield or changed milk composition in Holstein cows. These results, similarly to the present study, indicate no conclusive responses to cereal grain feeding.

Lehmann \& Meeske (2006) determined the effect of replacing maize with barley on milk production parameters of Jersey cows grazing kikuyu-ryegrass pasture. Five concentrates were used with different maize and barley ratios, that is, $100: 0 ; 75: 25 ; 50: 50 ; 25: 75$; and $0: 100$, respectively. The daily concentrate amount was $6 \mathrm{~kg}$ (on "as fed" basis) per cow per day. Cows fed concentrates containing $50 \%$ barley had significantly $(P<0.05)$ higher milk, 4\% FCM and protein yields than cows consuming concentrates containing $100 \%$ maize grain or $100 \%$ barley grain. These results seem to indicate that barley grain could replace maize grain in concentrates fed to Jerseys on cultivated pasture.

Moran (1986) found no differences $(P>0.05)$ in DM intake and milk yield in Friesian cows fed complete diets containing oat silage and lucerne hay together with $60 \%$ rolled grain consisting of either barley, wheat or oats. Fat-corrected milk yield of cows was higher $(P<0.05)$ on diets containing barley and wheat in comparison to oats while protein concentration was higher $(P<0.05)$ on the diet containing wheat grain. Cunningham et al. (1970), on the other hand, reported a lower $(P<0.05)$ milk yield and butterfat percentage for cows fed concentrate mixtures containing levels of soft red winter wheat that replaced maize and soybean meal at levels of $66.7 \%$ or $33.3 \%$. Lucerne hay and maize silage were used as forage sources. Faldet et al. (1989) reported no effect on DM and CP intake by cows fed complete rations, including concentrate mixtures of $0 \%, 40 \%$ or $60 \%$ hard red winter wheat with $45 \%$ sorghum silage (dry basis) forage source. Milk yield, however, was reduced $(P<0.05)$, that is, $28.8,28.0$ and $27.3 \mathrm{~kg} /$ day, respectively, with higher wheat inclusion levels.

Doepel et al. (2006) found that the feed intake and milk yield of Holstein cows receiving diets containing varying levels of wheat versus barley did not differ $(P>0.05)$. The milk protein content was lower in the wheat-fed cows in comparison with barley-fed cows. At the same time, milkfat content and fat yield were not affected $(P>0.05)$ by the treatments. They concluded that wheat could be included up to $20 \%$ by weight in the diet.

Feeding wheat grain has conventionally been regarded as a feed source that causes rumen acidosis, laminitis, depressed DM intake and milk fat. Combined with its traditional use as human food, this has resulted in it being used only on a limited scale in dairy rations. These problems do not seem to occur in all situations, as the level and the way in which wheat is being fed could affect the production response of cows. The present study indicated that, although only significant $(P<0.05)$ for the LH study, the DM intake of cows was reduced with higher wheat levels in diets using different forages. Over a longer term, this could have a negative effect on milk yield. This requires further study specifically with regards to the effect of feeding level of wheat in complete diets and in combination with other cereal grains.

\section{Conclusion}

The present study did not show conclusive negative results regarding the replacement of maize grain with wheat grain. Although the feed intake of cows was lower on the $100 \%$ wheat diet compared with the $100 \%$ maize diet, differences were significant only in the LH experiment. Milk yield parameters were not affected by increasing wheat levels. The only exception was that the fat percentage of milk and fat yield in the LH experiment were lower with a high level of wheat in the diet. In longer-term studies, a lower feed intake might have a greater negative effect on milk yield and other parameters. The amount of concentrates fed per day to cows would also affect the rumen environment and should be considered.

\section{Acknowledgements}

The authors thank J. de Vos and his staff for the milking, care and management of the experimental animals. The support of the Western Cape Agricultural Research Trust for financial management and part funding of the study is also gratefully acknowledged.

\section{References}

AOAC, 1995. Official methods of analysis. (16 ${ }^{\text {th }}$ ed.). Association of Official Analytical Chemists. Washington D.C., USA.

Berry, S.L. \& Cook, N.B., 2000. Locomotion scoring of dairy cattle. Zinpro Corp. 10400 Viking Drive, Suite 240. Eden Prairie, MN 55344. USA. www.zinpro.com.

Bredon, R.M., Stewart, P.G. \& Dugmore, T.J., 1987. A manual on the nutritive value and chemical composition of commonly used South African feeds. Department of Agriculture and Water Supply, 
Natal Region. Published by the Directorate of Agricultural Information, Private Bag X144, Pretoria. pp. 3.

Doepel, L., Cox, A. \& Hayirli, A., 2006. Wheat can be used as a partial replacement for barley in dairy cow diets. DRTC Dairy Day. Department of Agriculture, Food and Nutritional Sciences, University of Alberta, Canada. pp. 12-13.

Cunningham, M.D., Albright, F.L. \& Howard, W.T., 1970. Percent protein and amounts of soft red winter wheat for lactating cows. J. Dairy Sci. 53, 1787-1790.

Ensminger, M.E., Oldfield, J.E. \& Heinemann, W.W., 1990. Feeds \& Nutrition $2^{\text {nd }}$ ed. (Formerly, Feeds \& Nutrition-complete). The Ensminger Publishing Company. 648 West Sierra Avenue, Clovis, California 938612. pp. 85.

Erickson, J.P., 1985. Triticale: A review of its nutritional value for livestock, poultry. Feedstuffs 57, 20.

Faldet, M.A., Nalsen, T., Bush, L.J. \& Adams, G.D., 1989. Utilization of wheat in complete rations for lactating cows. J. Dairy Sci. 72, 1243-1251.

Gulmez, B.H., Gencoglu, H., Biricik, H., Deniz, G., Kara, Ç., Balci, F. \& Turkmen, I.I., 2010. The effect of starch sources with different degradability rates on milk production and composition in lactating cows. J. Biol. Environ. 4, 9-14.

Lehmann, M. \& Meeske, R., 2006. Substituting maize grain with barley grain in concentrates fed to Jersey cows grazing kikuyu-ryegrass pasture. S. Afr. J. Anim. Sci. 36, 175-180.

MacFie, H.J., Bratchell, N., Greenhoff, K. \& Vallis, L.V., 1989. Designs to balance the effect of order presentation and first-order carry-over effects in Hall tests. J. Sensory Studies 4, 129-148.

McDonald, P., Edwards, R.A. \& Greenhalgh, J.F.D., 1988. Feeding standards for reproduction and lactation. Chapter 19 in Animal Nutrition. ( $4^{\text {th }}$ ed). Longman Scientific and Technical, New York. pp. 420-425 \& 451.

McSweeney, C.S. \& Mackie, R.I., 1997. Gastrointestinal detoxification and digestive disorders in ruminant animals. In: Gastrointestinal Microbiology, Vol. 1. Eds: Mackie, R.I. \& White, B.A. Chapman and Hall, New York. pp. 583-634.

Moran, J.B., 1986. Cereal grains in complete diets for dairy cows: A comparison of rolled barley, wheat and oats and of three methods of processing oats. Anim. Prod. 43, 27-36.

Mulvany, P., 1977. Dairy cow condition scoring. National Institute for Research in Dairying. Reading, UK. Paper No. 4468.

Petit, H.V. \& Santos, G.T.D., 1996. Milk yield and composition of dairy cows fed concentrate based on high moisture wheat or high moisture corn. J. Dairy Sci. 79, 2292-2296.

SAS, 1999. SAS/STAT User's Guide, Version 9, $1^{\text {st }}$ printing. Volume 2. SAS Institute Inc, SAS Campus Drive, Cary, North Carolina 27513. USA.

Shapiro, S.S. \& Wilk, M.B., 1965. An analysis of variance test for normality (complete samples). Biometrika $52,591-611$.

Smith, W.A., Du Plessis, G.S. \& Griessel, A., 1994. Replacing maize grain with triticale grain in lactation diets for dairy cattle and fattening diets for steers. Anim. Feed Sci. Technol. 49, 287-295.

Stock, R.A., Sindt, M.H., Parrott, J.C. \& Goedeken, F.K., 1990. Effects of grain type, roughage level, and monensin level on finishing cattle performance. J. Anim. Sci. 68, 3441-3455.

Williams, E.J., 1948. Experimental Designs Balanced for the Estimation of Residual Effects of Treatments. Mathematical Statistics, Dec 1948, pp. 149-168. 